\title{
Increasing Students' Motivation in Writing through Diving and Climbing Strategy
}

\author{
Sri Minda, S.Pd., M.Hum ${ }^{1}$ \\ ${ }^{1}$ Fakultas Tarbiyah dan Ilmu keguruan IAIN Padangsidimpuan
}

\begin{tabular}{|c|c|}
\hline ARTICLE INFO & ABSTRACT \\
\hline $\begin{array}{l}\text { Article history: } \\
\text { Received Feb 04, } 2020 \\
\text { Revised April 29, } 2020 \\
\text { Accepted Jun 20, } 2020\end{array}$ & \multirow{5}{*}{$\begin{array}{l}\text { This research aimed to find the effect of teaching strategy on the } \\
\text { students' motivation in writing and the students' problems during the } \\
\text { strategy implementation. Climbing and Diving was the strategy that } \\
\text { was applied in this research. The design of the research is } \\
\text { experimental. The first year students were taken as the population of } \\
\text { the research. They are the Intensive language learning programme } \\
\text { students in IAIN Padangsidimpuan. Questionnaire and interview } \\
\text { were used to get the data. Likert scale was used in the questionnaire } \\
\text { to score the students' responses. From the calculation using t-test, the } \\
\text { t value = } 0.756 \text { is the t table } \alpha=0.05 \text {. It means that the students' } \\
\text { motivation in writing is significantly affected by Climbing and } \\
\text { Diving strategy. During the implementation of the strategy, the } \\
\text { students faced two dominant problems. They are time limitation and } \\
\text { no specific pattern. The short time offered by this strategy does not } \\
\text { give the students more chances to write and because of no pattern } \\
\text { makes students lose control in writing. }\end{array}$} \\
\hline $\begin{array}{l}\text { Keywords: } \\
\text { Climbing and Diving } \\
\text { Writing } \\
\text { students' motivation }\end{array}$ & \\
\hline $\begin{array}{l}\text { Clonflict of Interest: } \\
\text { None }\end{array}$ & \\
\hline . & \\
\hline None & \\
\hline \multicolumn{2}{|c|}{$\begin{array}{l}\text { Corresponding Author: Sri Minda, S.Pd.,M.Hum, Fakultas Tarbiyah dan Ilmu keguruan IAIN } \\
\text { Padangsidimpuan, E-mail: sriminda18@ gmail.com }\end{array}$} \\
\hline & $\begin{array}{r}\text { Copyright } @ \text { Association of Language Teachers in Southeast Asia. } \\
\text { All rights reserved }\end{array}$ \\
\hline
\end{tabular}

\section{Introduction}

\subsection{Subject Area of Interest}

The process of learning to write is so complex that need certain cognition of a text's generic structure, it is brought the manifestation of a complex set of knowledge and skills that bring the students to deliver their thoughts, idea, feeling or intention more mindful (Knapp and Watkins, 2005).

As what the researcher found in her observation that many students of the first year in IAIN padangsidimpuan made errors in writing. They were very bad in writing. The students who are not new English learners had low ability in learning that language, especially in writing skills. There is only little students who have good skill in writing. They often make mistakes in their writing.

Motivation defines as a ccomplex theory that is used to explain persistence, initiation or intensity, especially self behavior (Brophy, Jare, 2005). The motivation is the first thing that the students must have before they start to learn something (Z, Dornyei, 2001). Especially in learning foreign language which is extremely different with their mother tongue. This learning willingness is considered as motivation. It is not an easy work to start the learning without the students' motivation which creates new various problems for the teacher. It is taken into consideration from that aspect, to be able to make the learner active and desirable in learning process gains importance.

The data from the observation (data of students' writing score from Language Development Center IAIN Padangsidimpuan) proves that the writing scores of the students are very low. This data strengthen the researcher observation. The data is the average of all students' scores from all classes (2015/2016: 48 classes 
; 2016/2017: 50 classes; 2017/2018: 64 classes). From the data it is visible that the average score of writing is law. It is far from the standard score of writing which is 20 . The standard score is ruled by Indonesia Australian Language Foundation (IALF) Bali as the partner of IAIN Padangsidimpuan in running the Intensive English Programme. There is a slight decrease in academic year 2016/2017 which is 0.43 (11.78 to 11.35 ) and after that it went up to 11.75 in academic year 2017/2018 in which there is only 0.35 of increasing. Unfortunately, there is no significant increase of the total average of the score. The difference of the number is only about $0.03-0.43$. The total average of writing in academic year 2016/2017 is the lowest score (11.35) which means that only $56.75 \%$ out of 20 (the standard score of writing). The highest total average score is in academic year 2015/2016 which is 11.78 (58.9\%). It clearly describes that the effectiveness of teaching writing still weak. Most of the students are weak in writing. They only get a half of the standard score.

From the next observation done by the researcher that the student's ability in writing is poor in which the students only get 7 out of 20 . There areso many spelling errors found in the task. More than fifteen spelling errors found in it such as wont (want), orr (or), bat (but), baying (buying), tink (think), and so on, even she wrote Bahasa Indonesia in it (tentang). The idea of that writing was nothing. The student did not mention what topic she wrote about. Furthermore, she could not make correct simple present tense. For example, I'm from in Benhur. She put double preposition of place (from and in) in that sentence which is wrong. The preposition in is actually not important in that sentence. The writing is actually only a single paragraph and it less than 150 words as mentioned in the instruction of the writing.

\subsection{Related Studies}

A study related to the implementing of Climbing and Diving strategy found that this strategy give effect toward writing competency of the seventh grade students significantly. The result confirms that there was increasing in writing competency between the students taught by Climbing and Diving strategy and those taught by conventional strategy. The value of the t-test used is 0.05 which is higher than the value of the strategy 0.001 . It proves that the students' writing competency is significantly affected by Climbing and Diving strategy (Ni Made, 2014).

Moreover, a research found that among 35 students, there are only 10 students $(26.9 \%)$ that can get good score in writing while the other 28 students $(71.5 \%$ ) are unable to write good writing (Martha, 2014).

A related to the implementing of Climbing and Diving strategy found that this strategy give effect toward writing competency of the seventh grade students significantly. The result confirm that there was increasing in writing competency between the students taught by Climbing and Diving strategy and those taught by conventional strategy. It is proven by the calculation of the scores. The value of the $\mathrm{t}$-test used is 0.05 which is higher than the value of the strategy 0.001. This difference states that Climbing and Diving strategy significantly effect on the students' writing competency (Marjohan, 2014).

\subsection{Related Theory}

These phenomena explain that writing is considered as the most complicated skill in language learning. It is absolutely clear that from all skill in learning language, writing is the most complex skill for students to be mastered (Kang, shumin,2002). Most students feel hard to generate and organize the ideas.

Considering about solving those writing instructional problems, there are many types of teaching approach that can be applied. Climbing and Diving Strategy is effective in increasing the students' achievement in writing. According to the theory, this strategy is effective for Students' Writing Achievement since these strategies help the students to be more concentrate in the writing process (Minda, sri, 2011).

Another strategy that can be used in teaching writing is Climbing and Diving strategy. It is started by drafting process and then develop the drafts to acsess what the students have accomplished. In this process the students have time to dive their writing and put them selves as the reader (Mclever and Urquhart, 2005).

By climbing on their writing, some ineffective languages and grammatical errors can be revised. At the same time, the students can add greater details through the dive process. Climbing and diving means that the students can move back and forth to get the desired result.

Based on these facts, the researcher intended toconduct a research on the effect of Climbing and Diving strategy on students' motivation in writing expository. The researcher of this study wants to investigate the effectiveness of Climbing and Diving startegy upon the students' motivation in writing expository. The subject of the study will be limited for only the first year students of Intensive English Language Programme in IAIN Padangsidimpuan. 


\section{Methods}

Experimental reasearch was implemented in this research by using Two groups, Randomized Subjects, Posttest only Design. Langauge needs a comprehensive assessment (Brown, H.Douglas, 2004). There are two variables in this research, they are independent variable that is Climbing and Diving Strategy and dependent variable: students' motivation.

The Population of the research was the students of the first year of Intensive English Language Programme Class in IAIN Padangsidimpuan and the samples were taken 10\% from the total of population. There were two classes in this research. Each group consisted of 25 students. One class was experimental group and another class was control group. Climbing and Diving Strategy was applied in experimental group. Meanwhile, in control group there was no strategy implemented.

There are two kinds of instruments which were used to collect the data. They are questionnaire and interview. The 20-statement questionnaire was designed by using Likert scale (0-4). The questionnaire was about the students' motivation in writing. The questionnaire is the standard writing motivation questionnaire taken from The empirical development of an instrument to measure writing apprehension (J.A., \& Miller, M.D, Daly, 1975). The questionnaire were distributed to all the samples (students) after implementing the strategies. The data from the questionnaire was about scores and the scores were splitted based on the frequency. The researcher interviewed some students from the experimental groups to know the students' difficulties in writing by appliying Climbing and Diving strategy. The interview was unstructured interview. There were 10 students as the interviewee. The researcher asked the interviewee with prearranged questions. This interview was more informal and free flowing than a structured interview. The researcher wanted the nature of conversation allows for spontaneity and for questions to develop during the interview based on the interviewee's responses.

\section{Results and Discussion}

3.1 Result

The questionnaires were administered to 25 students in a class. Before distributing the questionnaire, the researcher implemented Climbing and Diving strategy in the class step by step. Then, the students did the questionnaire.

It can be seen from the distribution of the scale that the highest frequency of the student level agreement is value 3 which is nearly 300 (297). It means that $59.4 \%$ from all level agreement students confidently stated that they agreed with the statement of the questionnaire. That number is more than a half of the total percentage. Secondly, Many of the students said that they strongly agreed (value 4) with the statement in which 135 out of 500. It means the percentage of strongly agree is $27 \%$. The level of agreement, namely uncertain (value 2) jumps into $13.6 \%$ which is 68 . Two lowest percentages are value 1 is $0 \%$ which means disagree and value 0 is $0 \%$ which is strongly disagree. From the calculation of these scores, it can be said that the students could have sense of Climbing and Diving strategy effectiveness. All of the students selected strongly agree (value 4) and agree (value 3) for the items of questionnaire. It is clearly seen from the percentage that the Climbing and Diving strategy effects the students' motivation in writing expository, which is $86.4 \%$.

The questionnaire were administered to 25 students in control group. The class was not given any treatment. From the tabulation it was gained that there are five values in this questionnaire they are 4 (strongly agree), 3 (agree), 2 (uncertain), 1 (disagree), and 0 (strongly disagree). The top one percentage is value 2 which is more than a half of the total number. The percentage is $56.6 \%$. Value 3 comes next in the second position with 94 of the total number which is equals with 18.8\%. Disagree (value 1) is in the third position with $13 \%$. Not many of the students stated strongly agree which is value 4 . This value is only $8.6 \%$. And the lowest percentage is value 0 (strongly disagree) with only 15 out of 500 which equals with $3 \%$. The percentage of each value describes the students' responses toward the statement in the questionnaire. The first rank of frequency of the value in this group is value 2 which means uncertain. Based on this fact, the students of course did not know about the strategies used in this research because this group was given no treatment. So, it is natural if the highest frequency is value 2. The students were not sure about the statement related to the effectiveness of the strategy because they did not have the experience about the implementation of the strategy. It is reasonable if value 2 comes to the top of frequency in this group.

Then, the researcher made further analysis to see whether the Climbing and Diving strategy significantly affects the students' motivation in writing expository by using t-test formula. After calculating the scores using the formula, $\mathrm{t}$ value is 0.756 . Then, $\mathrm{t}$ value is compared to the $\mathrm{t}$ table $\alpha=0.05$. It means that $\mathrm{t}$ value $>t$ table. It means that Climbing and Diving strategy significantly effect the students' motivation in writing expository. Then, ha is accepted and ho is rejected.

The researcher made further analysis with the data distribution of questionnaires in controlled group by classifying the value based on the frequency. Based on the analysis, it can be seen that the highest frequency is value 2 which means uncertain. The percentage is $58.2 \%$. As what happened in cotrolled group 
I, the students in this group also felt a bit not sure about the effectiveness of the strategies. It is clear because the strategies were not implemented in those classes. So that is why the students chose uncertain. In the other hand, the lowest frequency is value 0 which means strongly disagree. The percentage of this value is only $3 \%$. The students' responses to value 4,3 , and 1 are not so significant. The three values are less than $20 \%$. The percentage of value 4 is $8.6 \%$. Then, followed by the percentage of value 3 which is $19.2 \%$. And the last percentage of value 1 is $11 \%$. Based on these percentages, it is fair that the highest students' responses toward the level of agreement to the questionnaire statements is uncertain (value 2). It is because the strategy was not implemented in this class.

\subsection{Discussion}

The 20-statement questionnaire was scored by using Likert scale. 0-4 are the scale used in this questionnaire. The highest score is 4 and the lowest one is 0 . It can be seen from the calculation of the questionnaires in experimental group that the students' responses to the questionnaire were mostly 3 (agree) and 4 (strongly agree). The highest percentage of the scale was scale 3 which is $59.4 \%$ with the total 297 . Mostly the students chose scale 3 which meant that they agreed to the statement. That number is more than a half of the total percentage. Secondly, Many of the students said that they strongly agreed (value 4) with the statement in which 135 out of 500. It means the percentage of strongly agree is $27 \%$. The level of agreement, namely uncertain (value 2) jumps into $13.6 \%$ which is 68 . Two lowest percentages are value 1 is $0 \%$ which mean disagree and value 0 is $0 \%$ which is strongly disagree. From the calculation of these scores, it can be drawn that this strategy affected the students' motivation performances in writing. All of the students selected strongly agree (value 4) and agree (value 3 ) for almost all the statements in the questionnaire.

The researcher made further calculation to test the hypothesis of the research in implementing Climbing and Diving strategy on students' motivation in writing expository. The result of the computation is $\mathrm{t}$ value $=0.756$. If it is compared to the $\mathrm{t}$ table $\alpha=0.05$. It means that $\mathrm{t}$ value $>\mathrm{t}$ table. It means that the students' motivation in writing expository is significantly affected by Climbing and Diving strategy. So that, ha is accepted and ho is rejected.

In line with the above explanation, a former research proves that Climbing and Diving strategy is significantly affects the students' achievement in writing. The researcher tested the students' writing ability in procedure text. The tests were administered into two tests, namely pre test and post test. Climbing and Diving strategy is implemented by the researcher. The result of the research showed that there was a significant improvement in the students' procedure text writing ability after being taught using Climbing and Diving strategy. The result of the pretest is 61.61 and post test is 77.43 . It is clearly seen that the students' score increased after taught by Climbing and Diving strategy. The data were analyzed by using t-test value in which the significance was determined by $\mathrm{p}<0.05$ (Pratiwi, 2016).

Another research in investigating the effectiveness of Climbing and Diving strategy in writing skill of recount text. The design of this research was experimental research. This research aimed at finding out whether there was a significant effect of Climbing and Diving strategy strategy on students' ability in writing recount text or not. The population of this research were the students grade X MAN Lubuk Alung in academic year 2015/2016. It consists of 180 students. The sampling technique was cluster sampling, and it was selected two classes, X4 treated through Climbing and Diving strategy while X3 was treated through conventional strategy. The data of this research were collected through writing test. The data analysis of posttest showed that the mean scoreof students' writing skill in experimental class were 77.75 with 6.51 standard deviation and the mean score of students' writing skill in control class were 67.58 with 6.42 standard deviation. The data was taken after both classes were given treatments for several times with calculation $=5.113$ and $t$ table $=1.645$. It means the score of tcalculated was bigger than the score of ttable $(\mathrm{tc}>\mathrm{tt}$ ). Based on the analysis, it was concluded that Climbing and Diving strategy strategy gave significant effect toward students' writing skill of recount text rather than conventional strategy. It was proven by students score in experimental class was higher than control class (Hamdani,et.al., 2016).

Another strategy which was implemented in one of the experimental groups in this research is Climbing and Diving strategy. It was found that it is significant toward the students' motivation in writing expository. Through the $t$-test calculation the result of the computation is $t$ value $=0.909$. If it is compared to the $\mathrm{t}$ table $\alpha=0.05$. It means that $\mathrm{t}$ value $>\mathrm{t}$ table. Statistically ha $>$ ho. It means that Climbing and Diving strategy significantly effect the students' motivation in writing expository. Furthermore, a 20-item questionnaires were given to the students in this group. And it was found that the students gave positive responses toward the use of Climbing and Diving strategy. They were motivated to write after the implementation. It can be proven from the data of the questionnaires that the highest frequency of the students' agreement is value or score 3 which means agree. It describes that the students agreed with the statements of the questionnaire related to the strategy. The agreement here means that they could feel the effectiveness of the strategy to increase their motivation in writing, so that they chose agree (value 3). 
Moreover, from the analysis of the questionnaire, the students' responses to the level of agreements were analyzed and it was found that the students were motivated in writing especially expository. It can be proven from their responses towards the items in questionnaire. The questionnaire used Likert scale such as 4 (strongly agree), 3 (agree), 2 (uncertain), 1 (disagree), and 0 (strongly disagree). The highes frequency in both classes (experimental group I and experimental group II) is value or scale 3 which is agree. Based on the analysis, most of the students agree with the statements related to the effectiveness of the strategies. It means that they could fell the effect of the strategies in motivating them to write. The students had positive input through the implementation of both strategies. After the implementation of the strategy they felt writing is not a difficult task anymore. The strategies gave the students easiness especially in writing. Then, finally the students are motivated to write because they already get effective and easy ways to write.

Related to the implementation of Climbing and Diving strategy. This strategy gives effect toward writing competency of the seventh grade students significantly. The result confirms that there was increasing in writing competency between the students taught by Climbing and Diving strategy and those taught by conventional strategy. It is proven by the calculation of the scores. The value of the t-test used is 0.05 which is higher than the value of the strategy 0.001. This difference states that Climbing and Diving strategy significantly affects on the students' writing competency.

Furthermore, it was also found that students face difficulty in writing through applying Climbing and Diving strategy. The first problem is the students had no enough time to think and explore their writing content. The duration of every step is only ten minutes which hard for students to have enough time thinking what they want to write. Because of the restricted duration, the students does not have enough time to write more drafts. The second difficulty is that loose of control. Many of the students have no control when they were writing. They did not have format to follow to write. Because of this freedom, the writing content was not satisfying.

\section{Conclusion}

Based on the analysis, the conclusions are drawn as follows: "Climbing and Diving strategy increased the students' motivation in writing significantly". Some problems that happened during the imprementation of the strategy are: the limited time makes students does not have enough chances to write more drafts. This strategy limits the time for the students to write. This limitation in fact, cause problem to the students. However, students need longer time to express their thoughts through writing. Besides the time, another problem is about the pattern of the writing. The absence of the pattern makes uncontrolled writing . In this problem students told that they often write whatever come up to their mind at that time. It is often they write without control.

\section{References}

Brophy, Jare. (2005). Motivating Students to Learn (3rd ed.). Taylor and Francis.

Brown, H. D. (2004). Language Assesment Principles and Classroo Practices. Longman.

Hamdani, et.al. (2016). The Effect of RAFT on Students' Achievement in Writing Recount Text at grade X MAN Lubuk Alung. English Department: State University of Padang, 9.

J. A., \& Miller, M. D, Daly. (1975). The empirical development of an instrument to measure writing apprehension. Research in the Teaching of English. Taylor \& Francis.

Kang, S. (2002). Methodology in Language Teaching, an Anthology of Current Practice. Cambridge University Press.

Knapp and Watkins, Megan. (2015). Genre, Text, Grammar. University of New South Wales. Marjohan. (2014). The Effect of RAFT Strategy and Anxiety Upon Writing Competency. Universitas Pendidikan Ganesha.

Martha. (2003). The Students' Ability in Creating a Writing Composition. State University of Medan. Mclever, U. (2015). Teaching Writing in the Content Areas. ASCD.

Minda, S. (2011). Improving The Students' Achievement in Writing Report Text by Applying RAFT. State University of Medan, 11.

Ni made et.al., Parilisanti. (2014). The Effect of RAFT and students' anciety in Writing. E-Journal Program Pascasarjana Universitas Pendidikan Ganesha Program Studi Pendidikan Bahasa Inggris, 2. https://media.neliti.com/media/publications/119202-EN-the-effect-of-raft-strategy-and-anxiety.pdf,.

Pratiwi, Yoesis Ika. (2016). The use of RAFT strategy in teaching writing procedure Text. Universitas Bandar Lampung Press, 21.

Z, Dornyei. (2001). Teaching and Researching Motivation. Psychological Corporation. 